\title{
超音速ジェットの三次元構造 (DSMC 計算の新衝突計算法) \\ 3D Structure of a Supersonic Jet (New Intermolecular Collision Scheme of DSMC Method)
}

\author{
○正 宇佐美 勝 （三重大）
}

\author{
Masaru USAMI, Mie University, 1515 Kamihama-cho, Tsu 514-8507
}

Key Words: Rarefied Gas, DSMC, Intermolecular Collision, Supersonic Jet, Shock Wave

\section{1.はじめに}

DSMC 法 (1) は希薄気体流の解析法として開発されたが, 計算機の発展に伴って, その適用範囲は, 連続流状態まで広 がる傾向にある. DSMC 法は, 計算の発散といった不安定要 素がなく, また, 境界条件も比較的与え易い, 一方, DSMC 法で最も問題となるのは, 流れ場のセル分割を, 平均自由行 程と同程度で行う必要があるという点である. 従来の衝突計 算法では，同一セルに含まれる任意の分子 2 個は，その相対 位置に関係なく衝突ペアとして選択されるため, セルを大き くすることはできない，もしセルを大きくできる計算法が確 立したなら, セル数も分子数も少なくなり, DSMC 法の適用 範囲は大きく広がる. 本報告では, 衝突する分子の位置に応 じて分子速度の補正を行った上で分子間衝突を行うという算 法で，セル長が大きくとも良好な結果を得る方法を考案した.

円形オリフィスから流出する超音速自由噴流 ${ }^{(2) ~(5) ~}$ は, 近 似的には軸対称と見なせるが, 㛜密には三次元的な不安定構 造を持ち，これがジェット騒音や超音速混合に深く関与する. 近年の報告 ${ }^{(6) \sim(9)}$ によると, 噴流境界が流れに沿って曲率を もつためテーラー・ダルトラ型不安定が発生し, 軸に垂直な断 面上で渦対が生ずると考えられている. そして，その渦対の ために，その断面上で噴流を眺めると花びら模様が観測され る. 著者はこれまでに, 有限体積法を用いた市販の流体解析 ソフトCFD2000を用いて,この花びら模様の観測を行って いる (図 1 ). 今回は, 上記の新衝突計算法をこの問題に適用 し, 円形オリフィスから流出するジェットの三次元歪み構造を DSMC 法で再現した.

\section{2. 新衝突計算法}

従来の衝突計算法では, セルが大きくなるとそれに比例し て二つの衝突分子の位置は離れるため, シミュレーションが 忠実に行われなくなる. 本計算法は, 衝突計算直前に一方の 分子 $\mathrm{P}$ を, あたかも, もう一方の分子 $\mathrm{Q}$ の位置に移動させた かのように分子速度の補正を行う. いま, 流れ場中の分子は, 全て, ある温度と流れ速度を持つ局所平衡状態の速度分布関 数 (Maxwell 分布) に従うものと仮定する. 分子 P の位置の 分布関数を $f_{1}$, 分子 $\mathrm{Q}$ の位置の分布関数を $f_{2}$ とし, 分子 $\mathrm{P}$ の速度が $f_{1}$ 上の一点 $\mathrm{A}$ にあるものとしよう (図 2). 衝突計 算に際して，このA 点を分布関数 $f_{2}$ 上のどこかに移せばよ いことになるが, 最も自然な方法は, $f_{1}$ 上の A 点位置と $f_{2}$ 上の位置が相対的に同じになるよう移動させることである (B 点).この B 点位置を求める計算は簡単である。いま, $x$ 方向 速度成分 $u$ の分布関数について考えると, $f_{1}$ と $f_{2}$ は次のよ
うに書ける.

$$
\begin{aligned}
& f_{1}=\frac{1}{\sqrt{2 \pi R T_{x 1}}} \exp \left\{-\frac{\left(u_{1}-U_{1}\right)^{2}}{2 R T_{x 1}}\right\} \\
& f_{2}=\frac{1}{\sqrt{2 \pi R T_{x 2}}} \exp \left\{-\frac{\left(u_{2}-U_{2}\right)^{2}}{2 R T_{x 2}}\right\}
\end{aligned}
$$

ここで, $R$ は気体定数, $T_{x 1}, T_{x 2}$ および $U_{1}, U_{2}$ は, $x$ 方向温 度および流速の $x$ 成分である. $f_{1}$ および $f_{2}$ をそれぞれ最大 值で無次元化し，それらを等しいとおくと，

$$
\frac{\left(u_{1}-U_{1}\right)^{2}}{T_{x 1}}=\frac{\left(u_{2}-U_{2}\right)^{2}}{T_{x 2}}
$$

したがって

$$
u_{2}=U_{2}+\left(u_{1}-U_{1}\right) \sqrt{T_{x 2} / T_{x 1}}
$$

分子間衝突の計算は, この修正された速度 $u_{2}$ を用いて行い, 得られた衝突後の速度 $u_{2}^{*}$ (C 点) は, 分子 $\mathrm{P}$ を元の位置に戻す 操作のために, 式 (5) を用いて再び修正される (D 点).

$$
u_{1}^{*}=U_{1}+\left(u_{2}^{*}-U_{2}\right) \sqrt{T_{x 1} / T_{x 2}}
$$

さて, 式 (4)(5) を用いるためには分子 $\mathrm{P}$ と $\mathrm{Q}$ それぞれの位置 における流速と温度のデータが必要である. したがって, 最初 は，従来の計算法でセル中心の流速と温度を仮に求めておか ねばならない，セル内の任意位置における值は，隣り合うセ ル中心の值を直線で結び内挿 (一部は外挿) で求める. DSMC 法の長い繰返し計算の中で, 従来の方法による計算は最初の 1 回だけでよく, 以降は, 新衝突計算法によって流速と温度の データが逐次更新される，なお，新衝突法の計算 1 回に要す る時間は, 従来の計算法より $10 \sim 20 \%$ 増加する.

\section{3. 結果}

新衝突計算法を自由噴流の $3 \mathrm{D}$ 解析に適用する前に, 1 次元 垂直衝撃波および 2 次元正方空洞内の渦に適用し良好な結果 を得た。さらに軸対称噴流に適用したところ, マッハディス ク近傍の変化が激しい場所では，完全修正 (100\%補正) はか えって流れ場に歪みを生じる結果となることが判明した。こ れらのことを踏まえ，今回の 3D 計算では，まずは，補正を本 来の $50 \%$ で行うこととした. 50 \% 補正とは, セル中心から 分子 $\mathrm{P}$ まで (あるいは $\mathrm{Q}$ まで) の距離を $50 \%$ に減じてそれぞ れの位置の温度と流速を算出寸る方法である。

クヌッセン数 $K n$ (上流よどみ点の平均自由行程 $\lambda$ を円形オ リフィスの直径 $d$ で割算) を $3 \times 10^{-5}$, 圧比を 50 とし, 従 来の計算法と新衝突計算法でそれぞれ結果を求め比較した。使

日本機械学会東海支部第52期総会講演会講演論文集（'03.3.14--15）No.033-1 
用したセルの数は約 1300 万個, 分子数は約 4000 万個である. アルゴン単一気体を対象とし VHS 分子モデルを使用した. 三 次元計算であるため, 流れ場の温度と速度のデータを記憶す るメモリも膨大になる. 従って, 補正計算は流れ場の中で重 要と思われる部分だけに限定し，記憶のための格子も衝突計 算用セルよりさらに粗い間隔で作成した。 図 3 は, 円形オリ フィスより下流の流れ場の密度等值線を $z=0$ の $x$ - $y$ 断面で 比較したもので, 上図が従来の計算法, 下図が新衝突計算法 によるものである，等值線の描き方は，両図，全く同じ方法で ある.マッハディスク近傍や反射衝撃波近傍の等值線が, 新 衝突計算法の方がより密に表現されており, 粗いセルを使う ことで生じる密度変化の緩慢が解消されている。図 4 は, 噴 流中心軸に垂值な断面 $(x / d=4.74$ および 5.8$)$ で眺めた密度 等值線の比較である. 図 1 の連続流 CFD 計算の結果ほど鮮明 には現れていないものの, 密度の花びら模様は, 新衝突計算 法で求めた結果の方がよりはっきりと再現されている.なお, 現在, 補正 50 \%をマッハディスク近傍のみに限定 (他は 100 \%補正) して, 新衝突計算法によるシミュレーションを実行中 である.

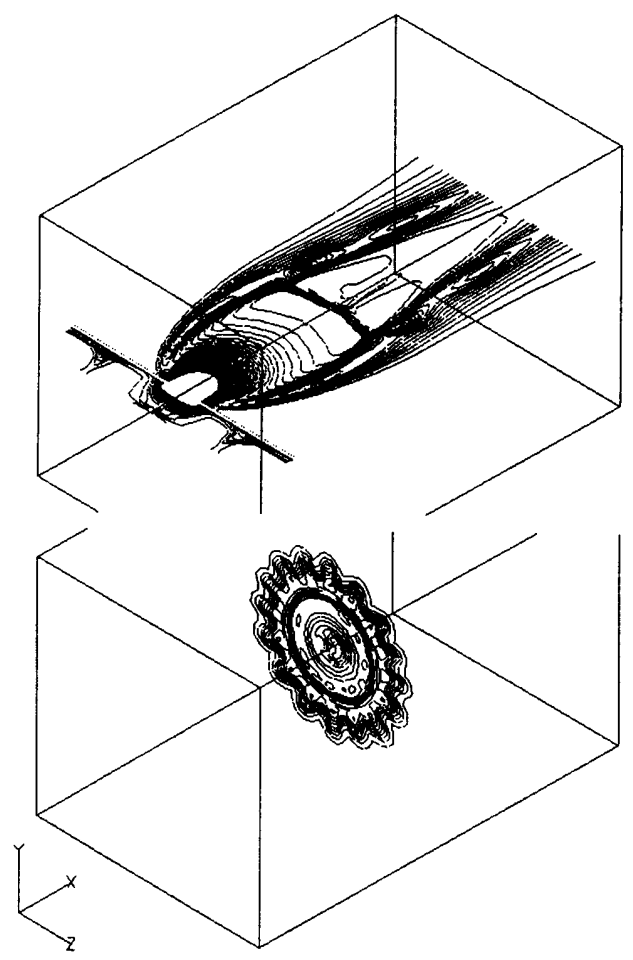

Fig. 1 Density profiles of the free jet by the continuum calculation (CFD2000)

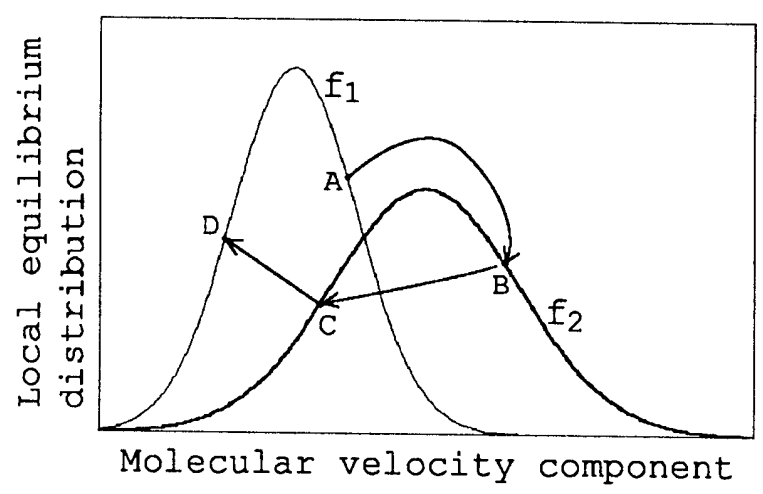

Fig. 2 Modification of velocity in the new intermolecular collision scheme
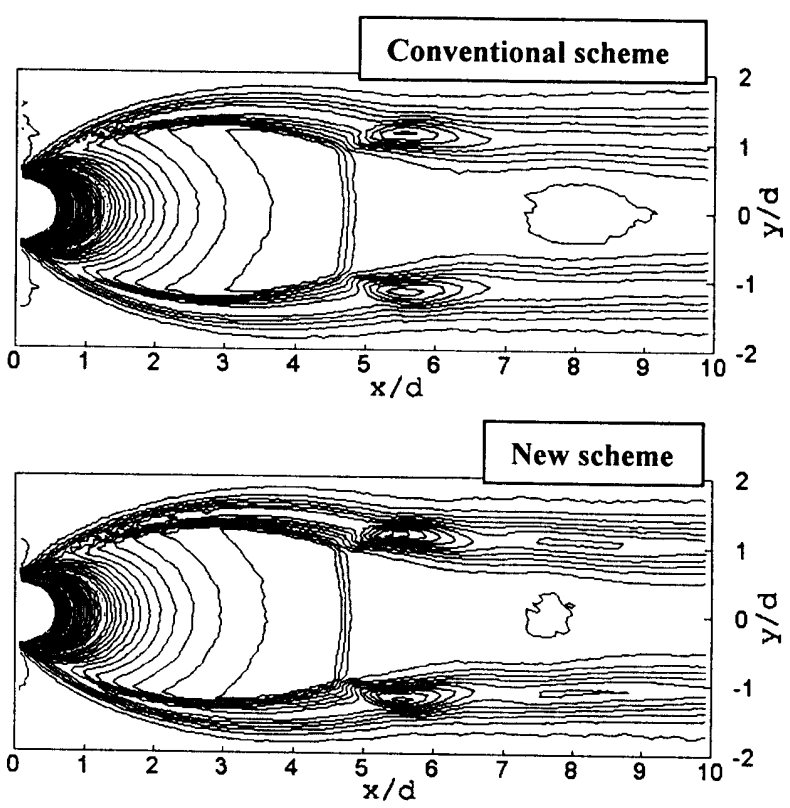

Fig. 3 Density contours of the supersonic free jet
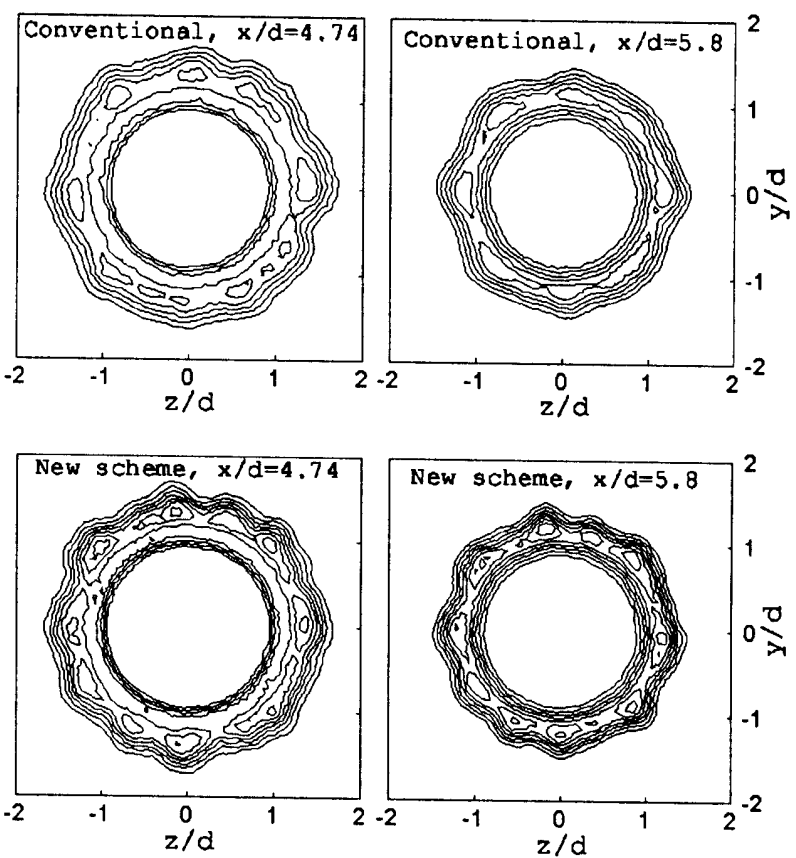

Fig. 4 Density contours in planes normal to the jet axis

\section{文 献}

(1)Bird,G.A., Molecular Gas Dynamics and the Direct Simulation of Gas Flows, (1994), Clarendon.

(2) 宇佐美・手島, 機論, 62-598B (1996), pp. 2215-2222.

(3) 宇佐美・手島, 機論, 64-620B (1998), pp. 1112-1119.

(4) 宇佐美・手島, 機論, 65-630B (1999), pp. 444-450.

(5) 宇佐美・手島, 機論, 68-666B (2002), pp. 344-351.

(6)Novopashin, S.A. and Perepelkin, A.L., Physics Letters A, 135-4,5 (1989), pp. 290-293.

(7)Krothapalli, A., Buzyna, G. and Lourenco, L., Physics of Fluids A, 3-8 (1991), pp. 1848-1851.

(8)Arnette, S.A., Samimy, M. and Elliott, G.S., Physics of Fluids A, 5-1 (1993), pp. 187-202.

（9）手島，第 29 回流体力学講演会講演集, (1997), pp. 297-300. 